\title{
History, Narratives and Realities
}

\section{Engagements with the Past and Present in Southern African Literature}

\author{
Mbongeni Zikhethele Malaba \\ University of KwaZulu-Natal, Pietermaritzburg, South Africa \\ Malabamz@ukzn.ac.za \\ Henning Melber \\ University of Pretoria, South Africa; University of the Free State, \\ Bloemfontein, South Africa; Nordic Africa Institute, Uppsala, Sweden \\ Henning.Melber@nai.uu.se
}

The brutal violence of colonisation and subsequent white settler minority regimes have left a lasting legacy on the structures of societies as well as the mindsets and mental dispositions of the people in Southern Africa. Notably so, Apartheid as a special kind of colonial white minority rule left traces and consequences lasting far beyond the declaration of Independence in Zimbabwe (1980), in Namibia (199o), and the establishment of a democratic political system in South Africa (1994). ${ }^{1}$ Public discourses as well as cultural narratives and the arts are still much affected by the history in the present, reminding of one of William Faulkner's best-known lines from the theatre play "Requiem for a Nun," that "the past is never dead, it is not even past."

This issue of MATATU focuses to a large extent on coming to terms with colonial expropriation and subsequent identity politics, not least as reproduced in heroic narratives and patriotic history created for a special brand of nation building in the post-colonial societies of Southern Africa under liberation movements as governments. The following critical explorations revisit the impact of colonial violence as well as the counter violence by anti-colonial movements and the subsequent processes of establishing new forms of rule. Post-colonial realities have often not overcome the colonial legacy but reproduced features and aspects of the systems against which the liberation struggle was waged. This merits the question and nurtures doubts whether the ideals

1 See i.a. Henning Melber, "No Rainbow Yet in Sight: Southern Africa under Liberation Movements as Governments," The Round Table, 108.5 (2019): 531-541. 
proclaimed and underpinning these struggles for self-determination were realised, or whether the quest was for unbridled power, under the guise of bringing freedom, social justice and democracy.

The social transformation of Southern African societies shaped by a settler colonial brand can at best be characterized as a transition from controlled change to changed control. The result is a new ruling political elite operating from commanding heights, whose foundations are further strengthened by selective heroic narratives and memories related to the wars of liberation. These struggle credentials serve as claim to entitlements and create new (to some extent invented) traditions to establish an exclusive post-colonial legitimacy under the sole authority of one particular political agency of social forces. The processes and their results have since the turn of the century increasingly been labelled "limits to liberation." These have in the meantime become explored for Southern Africa, mainly with regard to our cases of Zimbabwe, Namibia and South Africa. ${ }^{2}$

Part of the heritage, as a growing number of critical assessments have shown, are not only the internalised dispositions. What has shaped and impacted on the post-colonial societies - in as far as they deserve to be qualified as postcolonial—are also socio-economic structural constraints and the reproduction of class interests in modified new or adjusted forms and features. A luta continua (the struggle continues) as a popular slogan of the struggle days, has been perverted into the translation 'the looting continues.' An elite pact benefits the new rulers through a perpetuation of old class interests within a new setting and blend, often under the disguise of 'affirmative action.' Meanwhile, in response to new forms of self-enrichment by those in official jargon declared as 'previously disadvantaged,' the popular struggles of civil society and social movements, more so than other political parties (which often only seek access to the honey pots, too), moves into centre space. The policy failures resulting in a lack of delivery due to a lacklustre performance of governments turned into self-enrichment schemes, as well as the dismal performance of opposition parties, demand a re-positioning and the continued search and battle for a society which allows its members some kind of true emancipation. There

2 See i.a. Henning Melber, ed. Limits to Liberation in Southern Africa: The Unfinished Business of Democratic Consolidation (Cape Town: HSRC Press, 2003); Sara Rich Dorman, "Post-Liberation Politics in Africa: Examining the Political Legacy of Struggle," Third World Quarterly 27.6 (2006): 1085-1101; Nicola De Jager \& Pierre du Toit, ed. Friend or Foe? Dominant Party Systems in Southern Africa: Insights from the Developing World (Cape Town: UCT Press and Tokyo/New York/Paris: United Nations UP, 2013); Roger Southall, Liberation Movements in Power: Party \& State in Southern Africa (Woodbridge: James Currey and Pietermaritzburg: U of KwaZuluNatal P, 2013). 
remains a dire need to secure human dignity and decency, originally believed to be an integral part of the motivating desire when fighting against settlercolonial rule.

There are increased efforts-in scholarly as well as popular non-fictive and creative writings - to evaluate the degree of coherence or dissonance between the stated objectives and declared promises of those in power and the social realities and perceptions among ordinary people. Were the promises simply rhetorical manipulation of the populace's cherished dreams or do they resonate with those governed? If one can rely on electoral performances, then the liberation movements as governments have gradually lost at least some of their credibility and support among those voting since they resumed office in these countries.

Michael Chapman explores the manifestations of belonging within South African literature in search of identities and a home since the 1970s. He interrogates if there is a South African nation and if so, what its mythos might be. A national cultural identity, he argues, is at best ambivalent. As he observes, disillusionment over 'rainbowism' promoted "a disillusionment with big politics, with a corrupt and rapacious elite in state power; it is a disillusionment, however, that has released, paradoxically, new energies in an onward, often awkward transition from societal aspiration to a 'freedom' of personal attitude and expression." In that sense, the 'limits to liberation' in 'big politics' has fueled the search for individual emancipation and belongings beyond the patriotic narrative.

A 'patriotic narrative' of a special South African brand has been-and continues to be, albeit in a modified and adapted way - the volksmoeder for white Afrikaans-speaking women. Christi van der Westhuizen traces the original heroic-feminist narrative originating from the role of these women in the Anglo-Boer War. Being marginalized in official memory, the notion has been revitalized with differing interpretations and connotations in current society. As a progressive option, middle-class white Afrikaans-speaking women embraced the new democratic South Africa and turn a back to exclusivity and whiteness as determination of identity. In contrast and direct contradiction, another version of the volksmoeder reinforces the gendered stereotype of a mother of the Afrikaner enclave nation as opposed to the rainbow vision. According to van der Westhuizen, this documents the "limits to, but also the potential of, the liberation of women identified as Afrikaners in postcolonial South Africa," 
which "can be traced by reading the contradictory narratives of the volksmoeder as journeys of the unlikely heroine."

In the subsequent articles, Namibia features most prominently as hitherto maybe most neglected of the selected countries when it comes to the exploration of colonial and post-colonial trajectories in engagements by fiction and poetry. The body of Namibian creative writing has only recently been documented more comprehensively and in a more nuanced, in depth manner. ${ }^{3}$ The articles by Chris Saunders, Mbongeni Malaba and Henning Melber illustrate the common strands that bind South Africa, Namibia and Zimbabwe in what has been called 'struggle literature.'

Chris Saunders assesses and compares the forms of memorialisation of the struggle history in Namibia and South Africa. He points as much to the differences as to the commonalities. Namibia's public commemorations cultivate the dimension of the armed struggle organised from exile over and above any other forms of resistance, while in South Africa the internal struggles feature more prominently. As a flip side to the emphasis of the military component and its masculinity in Namibia's anti-colonial war, the dehumanising effects of the control by SWAPO securocrats over the civilians has gradually brought much more sobering counter narratives to the fore. South Africa's long history of civil resistance to Apartheid by more complex and nuanced social forces with differing ideological and organisational forms of resistance has on the other hand resulted in a far more diversified and less militaristic symbolism and memory culture.

Mbongeni Malaba uses six life histories from the Namibian struggle to illustrate that memories matter. The three recollections of the rather prominent male SWAPO activists contrast markedly with the more personal memories of the three women. They document that 'heroism' has gendered and generational versions and that engagements with one's own experiences show different degrees of privacy and official history. He concludes: "Collectively, these works ask challenging questions about the price that was paid in human terms and whether the outcomes of the struggle are praiseworthy or not."

Henning Melber then seeks to deconstruct the heroic narratives by contrasting the dominant glorification in the Namibian public sphere with some of the 'hidden histories' and trajectories. As counter narratives based on personal victimization experiences, they disclose realities of the armed struggle and its consequences which do not have much of heroism and do not feature

3 See Sarala Krishnamurthy \& Helen Vale, ed. Writing Namibia: Literature in Transition (Windhoek: UNAM Press, 2018). 
in the official historiography. By being made accessible, though not officially recognized, they are important markers of perseverance and civil courage. The article ends with the presentation of a hardly known exiled poetic voice of a former victim of swAPO's human rights violations, documenting how humanity can be regained by speaking truth to power.

The next two articles revisit the first large-scale atrocities with lasting traumatic impact on collective memories of Namibian communities. They present different forms of engagement with the German genocide committed among the Ovaherero and Nama and thereby show that, despite having been committed more than a century ago, this constitutes much more than a historical episode' and remains a festering wound in the current day-to-day interactions with the German descendants of the time, both in Namibia and in Germany. After all, the genocide committed was only acknowledged by the German Foreign Ministry in 2015. Since then, bilateral negotiations between the two governments have been trying to find a way how best to come to terms with the ugly past.

Heike Becker documents a kind of renaissance of the genocide bringing back this history, by engaging with the subject also in novels. She compares several fictional stories on the subject from different narrative perspectives of the protagonists with an oral-history based biography and concludes: "[ $t$ he literary imagination of the events that have shaped Namibian history thus makes a significant contribution to challenging the social archive of collective memory." By doing so, these recent accounts highlight the ongoing efforts to give due recognition to the traumatic past and recognize the legitimate claims by the descendants of the Ovaherero and Nama, who do not feel adequately represented and involved as agents in the current negotiations between the Namibian and German governments. Sarala Krishnamurty adds another particular engagement with one of the novels included in Becker's article, seeking to lay bare its ambiguities and scrutinising the 'colonial gaze' by applying postcolonial and feminist perspectives. ${ }^{4}$

Returning to the socio-economic and -political realities of current Namibian society, Renzo Baas contrasts the focus of two novels on living conditions and expectations created and nurtured by political promises prior to Independence with their (lack of) realisation since then. His conclusion that "swAPo has not

4 Interestingly, another recent effort (not mentioned in either article) to engage with the subject by means of fiction was inspired by a settler family history going back to the time: Zirk van den Berg, Parts Unknown (Cape Town: Kwela Books, 2018). André Brink's, The Other Side of Silence (London: Secker \& Warburg, 2002), which won the African regional leg of the Commonwealth Writers Best Book Award in 2003, could also be considered in this context. 
delivered on many of the hopes of its (fictional) citizens or supporters" finds its current confirmation in the fact, that for the first time since Independence in the parliamentary and presidential elections of 27 November 2019 the party and its presidential candidate received significantly fewer votes than in previous elections of the last 25 years. Furthermore, the author of one of the novels decided after several conflicts with the party to leave Namibia in early 2019 for self-imposed 'exile.'

Bruno Arich-Gerz pays tribute to specific experiences by the fimbifimbi (chameleons), a self-reference by a unique group of several hundred Namibians. They were transferred as children from a war-torn refugee camp in Southern Angola to a school in the German Democratic Republic in the aftermath of a South African air raid with devastating consequences. Trained to become a new administrative and political elite, German unification and Namibian Independence abruptly ended their special upbringing. Returned to the land of their parents, they were dumped and left on their own to find ways to adjustor get lost. As "Africans with a German past" they have in various forms and with different success arranged themselves with their situation and identities since then, more or less at the margins of the heroic narrative and patriotic history.

Hugh Ellis presents a niche at the margins of Namibian society's establishments where a younger generation has created a form of sub-culture with features of a counter-narrative. As he shows, performance or 'spoken word' poetry has gained a significant foothold among youth in urban Namibia. This scene does not oblige the dominant restrictive norms and values but recognises diversity and deviating identities and forms of articulation. To some extent, this can be considered the alternative vanguard seeking new ground. Their form of emancipation is political in a different way and maybe most advanced in transcending the limits to liberation' into forms of individual emancipation within the urban confinements of a safe space.

Finally, Manfred Loimeier has a close look at two novels on Zimbabwe and South Africa published in 2013. They display the hangovers by comparing the hopes and expectations with the realities after white minority rule. Both share the disillusionment over what has not been achieved by asserting that "the ideals of freedom, democracy and independence have not been fulfilled by the governments that assumed power." On balance, this seems the case for all three liberation movements as governments after close to 40,30 and 25 years in office respectively, with which current fiction seeks to come to terms in different ways and forms. 


\section{In Memory of Geoffrey V. Davis (1943-2018)}

Geoff Davis was a member of the advisory board of this journal since its foundation in 1987. In 199o he joined the editorial board and took a lead role since then. His many interests included a strong focus on Southern African literature. ${ }^{5}$ The idea for this guest edited issue was originally discussed with Geoff. Shortly after we had agreed on its realization, he succumbed after a short battle to cancer, diagnosed only a very short time earlier. We mourn the loss of a committed colleague and deeply regret that he was denied to accompany us through the work in progress to see this result of a project jointly decided. We dedicate this issue to his memory. 6

\section{Works Cited}

Brink, André, The Other Side of Silence (London: Secker \& Warburg, 2002).

Davis, Geoffrey V., ed. Crisis and Conflict: Essays on Southern African Literature-Proceedings of the XI Annual Conference on Commonwealth Literature and Language Studies in German Speaking Countries, Aachen-Liège, 16-19 June, 1988 (Essen: Die Blaue Eule, 1990).

De Jager, Nicola \& Pierre du Toit, eds. Friend or Foe? Dominant Party Systems in Southern Africa:Insights from the Developing World (Cape Town: UCT Press and Tokyo/New York/Paris: United Nations UP, 2013).

Dorman, Sara Rich, "Post-Liberation Politics in Africa: Examining the Political Legacy of Struggle," Third World Quarterly 27.6 (2006):1085-1101.

Krishnamurthy, Sarala \& Helen Vale, ed. Writing Namibia: Literature in Transition (Windhoek: UNAM Press, 2018).

Melber, Henning, ed. Limits to Liberation in Southern Africa: The Unfinished Business of Democratic Consolidation (Cape Town: HSRC Press, 2003).

Melber, Henning. "No Rainbow Yet in Sight: Southern Africa under Liberation Movements as Governments," The Round Table, 108.5 (2019): 531-541.

Schulze-Engler, Frank. "Geoffrey V. Davis (1943-2018)—-In Memory of a Roving Scholar," Matatu, 5 o.1 (2018): 1-3.

5 See, for example, Geoffrey V. Davis, ed. Crisis and Conflict: Essays on Southern African Literature-Proceedings of the XI Annual Conference on Commonwealth Literature and Language Studies in German Speaking Countries, Aachen-Liège, 16-19 June, 1988 (Essen: Die Blaue Eule, 1990).

6 For a recognition of Geoff Davis and his work see Frank Schulze-Engler, "Geoffrey V. Davis (1943-2018) - In Memory of a Roving Scholar," Matatu, 50.1 (2018): 1-3. 
Southall, Roger. Liberation Movements in Power: Party \& State in Southern Africa (Woodbridge: James Currey and Pietermaritzburg: U of KwaZulu-Natal P, 2013). van den Berg, Zirk. Parts Unknown (Cape Town: Kwela Books, 2018). 